\title{
EVALUASI DESAIN BARU INSTAGRAM @FSRDUSAKTI SEBAGAI MEDIA BRANDING FSRD UNIVERSITAS TRISAKTI
}

\author{
Elda Franzia Jasjfi ${ }^{1}$, Resky Annisa Damayanti ${ }^{2}$, Valentina Ayu Puspaningtyas ${ }^{3}$, Karina L. Sastranegara ${ }^{4}$ \\ ${ }^{1,3,4}$ Program Studi Desain Komunikasi Visual, Fakultas Seni Rupa dan Desain, Universitas Trisakti \\ elda@trisakti.ac.id¹ ${ }^{1}$,resky_annisa@trisakti.ac.id², ayuvalentinaa@gmail.com³, \\ karinaluthfiya@gmail.com ${ }^{4}$
}

\begin{abstract}
Abstrak
Fakultas Seni Rupa dan Desain (FSRD) Universitas Trisakti memiliki akun Instagram @fsrdusakti sejak tahun 2016. Hasil penelitian awal, ada ketidakpuasan dari pengguna terhadap desain media sosial Instagram @fsrdusakti yang dinilai kurang tertata rapi dan tidak menunjukkan identitas visual yang menarik dan interaktif. Berdasarkan masukan tersebut, Fakultas Seni Rupa dan Desain Universitas Trisakti meluncurkan desain baru Instagram @fsrdusakti pada puncak perayaan 50 tahun FSRD Universitas Trisakti pada tanggal 23 November 2019 lalu. Sebagai salah satu media branding Fakultas Seni Rupa dan Desain Universitas Trisakti kepada khalayak sasaran, desain media sosial Instagram @fsrdusakti perlu dievaluasi, yaitu bagaimana pesan komunikasi visual branding disampaikan melalui elemen visual karakter ilustrasi dan warna. Metode pada penelitian ini adalah metode kualitatif dengan deskripsi analitis terhadap keberadaan desain Instagram @fsrdusakti. Pengumpulan data dilakukan melalui observasi visual dan kuesioner kepuasan kepada pengguna yang meliputi civitas akademika dan siswa SMA sebagai calon mahasiswa. Analisis evaluatif dilakukan berdasarkan data penelitian terhadap (a) Warna (b) Karakter ilustrasi, (c) Instagram feed pada akun Instagram @fsrdusakti. Hasil dari penelitian ini adalah penjabaran evaluatif terhadap rangkuman analisis dan rekomendasi terhadap pengembangan desain media sosial Instagram @fsrdusakti yang akan bermanfaat untuk Fakultas Seni Rupa dan Desain Universitas Trisakti.
\end{abstract}

Kata Kunci: media sosial, Instagram, branding, FSRD Universitas Trisakti

\begin{abstract}
Faculty of Art and Design Trisakti University has Instagram account @fsrdusakti since 2016. The early research result showed, there has an unsatisfied user that mentions the design of social media Instagram @fsrdusakti that are unattractive and not interactive enough for the user. Based upon the recommendations, the Faculty of Art and Design Trisakti University had launched a new design of Instagram @fsrdusakti on November 23, 2019, which was the 50th celebration day of the Faculty of Art and Design Trisakti University. As one of the Faculty of Art and Design Trisakti University's media branding to the audiences the evaluation of social media design, Instagram @fsrdusakti needed. How visual branding communication message is conveying to the user through illustration character and colors. The research method used is a qualitative method with a descriptive-analytical review of the design. Data collected through visual observation and questionnaires to the users such as academic and high school students as prospectus students. The evaluative analysis was carried based on data research of (a) Colors, (b) Illustration characters, (c) Instagram feed on Instagram account @fsrdusakti. The result of this research is an evaluative explanation of analysis and recommendation about social media design development of Instagram account @fsrdusakti that will support the Faculty of Art and Design Trisakti University.
\end{abstract}

Keywords: social media, Instagram, branding, FSRD Universitas Trisakti 


\section{PENDAHULUAN}

Media sosial merupakan media online yang memudahkan penggunanya untuk berkomunikasi dan berinteraksi dalam satu ruang virtual. Melalui media sosial komunikasi dapat berlangsung secara interaktif dalam bentuk saling berbagi konten, berkomentar, dan menciptakan isi percakapan pada laman media sosial tertentu. Saat ini media sosial biasa digunakan sebagai media promosi yang efektif karena mampu menyentuh langsung penggunanya dan dipercaya mampu memberikan respon secara langsung. Keunggulan lain adalah ruang virtual yang digunakan mampu menyebarkan informasi secara luas dan cepat.

Berdasarkan data Global Digital Report 2019 dari situs https://wearesocial.com/globaldigital-report-2019 yang diunduh pada tanggal 8 Maret 2019, Instagram merupakan salah satu media sosial yang sering digunakan di Indonesia selain Youtube, Whatsapp, dan Facebook (Kemp, 2019). Instagram berkembang menjadi peluang yang besar bagi pelaku bisnis, entertainment, komunitas, pemerintah, dan institusi dalam melakukan kegiatan promosi. Salah satu kelebihan dalam Instagram adalah penggunaan fiturnya mudah dan menekankan pada bentuk visual dan audio, seperti foto dan video. Kegiatan promosi dapat memanfaatkan fitur tersebut dengan merancang konten yang menarik, interaktif, informatif, dan rapi. Instagram memiliki fitur lain yaitu hashtag yang mempermudah pencarian pada konten-konten tertentu dengan jangkauan yang luas, sehingga mempermudah kegiatan promosi (Atiko, Sudrajat, \& Nasionalita, 2016).

Beberapa keunggulan tersebut menjadikan Instagram sarana potensial bagi media promosi berbagai produk dan jasa, termasuk untuk institusi pendidikan. Penelitian menunjukkan bahwa aplikasi media sosial Instagram yang menonjolkan foto dan visual terbukti memiliki korelasi kuat dalam mempengaruhi minat beli konsumen (Indika \& Jovita, 2017). Beberapa perguruan tinggi terkemuka di Indonesia telah memanfaatkan Instagram sebagai media promosi. Instagram berfungsi untuk mempererat social engagement terhadap civitas akademika dan masyarakat luas, sejalan dengan fungsi Tridharma Perguruan Tinggi yang berkaitan dengan pendidikan, penelitian, dan pengabdian kepada masyarakat. Fakultas Seni Rupa dan Desain Universitas Trisakti juga telah memiliki akun Instagram @fsrdusakti sejak tahun 2016 dan akun-akun lain yang dikelola oleh program studi Desain Interior @interior.trisakti, Desain Produk @desainproduktrisakti, Desain Komunikasi Visual @dkvusakti, Fotografi @fotografi_trisakti, Magister Desain Produk @magisterdesaintrisakti, D3 DKV @psd3dkvusakti ("FSRD Universitas Trisakti," 2020). Akun Instagram program studi berfungsi sebagai dokumentasi kegiatan program studi, sedangkan akun @fsrdusakti memiliki fungsi pembentuk branding Fakultas Seni Rupa dan Desain Universitas Trisakti.

Penelitian awal (Putri, 2019) mengemukakan bahwa ada ketidakpuasan dari pengguna tentang desain media sosial Instagram @fsrdusakti yang dinilai kurang tertata rapi dan tidak menunjukkan identitas visual yang menarik dan interaktif. Berdasarkan masukan tersebut, Fakultas Seni Rupa dan Desain Universitas Trisakti meluncurkan desain baru Instagram @fsrdusakti pada puncak perayaan 50th FSRD Usakti pada tanggal 23 
November 2019 yang lalu. Dengan adanya desain baru tersebut maka terdapat perubahan desain pada media sosial Instagram @fsrdusakti saat ini.

Desain baru menyampaikan pesan komunikasi branding baru kepada penggunanya. Oleh karena itu maka desain media sosial Instagram @fsrdusakti sebagai salah satu media branding FSRD Universitas Trisakti kepada khalayak sasaran perlu dievaluasi lebih lanjut. Berdasarkan latar belakang tersebut, maka masalah penelitian ini adalah bagaimana warna, karakter ilustrasi, dan desain feed pada Instagram @fsrdusakti menyampaikan branding FSRD Universitas Trisakti kepada penggunanya. Hasil dari evaluasi desain tersebut bermanfaat untuk pengembangan keilmuan Desain Komunikasi Visual khususnya peran desain media sosial, untuk pengembangan kurikulum Program Studi Desain Komunikasi Visual khususnya pemanfaatan media sosial dan media berbasis digital, bagi Fakultas Seni Rupa dan Desain Universitas Trisakti untuk pengembangan media sosial pembentuk branding ke masyarakat luas, serta bagi pengembangan wawasan pengguna media sosial Instagram pada umumnya.

\section{METODE PENELITIAN}

Metode penelitian menggunakan metode kualitatif deskriptif untuk menjabarkan hasil evaluasi desain objek penelitian. Objek penelitian adalah akun Instagram @fsrdusakti yang diakses melalui https://www.instagram.com/fsrdusakti/ atau melalui telepon seluler dengan aplikasi Instagram. Variabel penelitian ini adalah (a) Warna, (b) Karakter ilustrasi, (c) Desain feed. Pengumpulan data dilakukan dengan metode kuesioner dan observasi visual. Penyebaran kuesioner Google Form dilakukan secara online dengan target responden 100 orang dan mendapat hasil isian sejumlah 116 orang pengguna Instagram dalam waktu 2 minggu. Penyebaran kuesioner ini dilakukan untuk mengetahui reaksi dan persepsi terhadap desain baru Instagram @fsrdusakti dan apakah pesan tentang branding FSRD Universitas Trisakti tersampaikan melalui karakter ilustrasi dan warna yang digunakan. Kuesioner terdiri dari 30 pertanyaan. Pertanyaanpertanyaan pada kuesioner meliputi identitas diri, reaksi dan persepsi terhadap desain baru Instagram @fsrdusakti, kesan dan penerimaan terhadap elemen visual warna dan karakter ilustrasi serta desain feed pada Instagram @fsrdusakti. Pada masing-masing akhir bagian pertanyaan, responden diminta masukan/saran untuk pengembangannya. Keseluruhan pertanyaan bertujuan untuk menggali persepsi visual dan harapan pengguna terhadap akun media sosial Instagram @fsrdusakti. Hasil dari survei terhadap pengguna tersebut direlasikan dengan paparan deskriptif dari elemen desain akun media sosial tersebut yang digunakan untuk mengevaluasi desain baru pada akun sosial media Instagram @fsrdusakti.

Analisis data hasil survei dilakukan dengan pengkategorian, pentabulasian, dan pengkoordinasian data. Pengkategorian dan pentabulasian data berfungsi untuk pemanfaatan data yang dibutuhkan untuk menjawab pertanyaan penelitian dan untuk digunakan sebagai landasan analisis kualitatif selanjutnya. Analisis kualitatif deskriptif dilakukan dari data hasil penelitian yang terkumpul untuk mendefinisikan bagaimana konten, ilustrasi, dan warna pada akun media sosial Instagram @fsrdusakti 
menyampaikan pesan komunikasi visual kepada penggunanya. Pemaparan deskriptif digunakan untuk mengevaluasi desain baru pada akun tersebut.

Analisis dilakukan secara bertahap dari elemen visual (1) Warna, (2) Karakter ilustrasi, dan (3) Desain feed, untuk menjawab pertanyaan penelitian secara menyeluruh tentang penyampaian pesan komunikasi visual branding FSRD Universitas Trisakti melalui media sosial Instagram @fsrdusakti. Hasil dari evaluasi desain merupakan simpulan yang berisi rangkuman analisis dan rekomendasi terhadap pengembangan desain media sosial Instagram @fsrdusakti kepada pihak pengelola.

\section{HASIL DAN PEMBAHASAN}

\subsection{Fakultas Seni Rupa dan Desain Universitas Trisakti}

Fakultas Seni Rupa dan Desain Universitas Trisakti berdiri pada tahun 1969 sebagai bagian dari Fakultas Teknik Universitas Trisakti. Pada tahun 1996 Jurusan Desain berkembang menjadi Fakultas Seni Rupa dan Desain (FSRD) berdasarkan Surat Keputusan Direktur Jenderal Pendidikan dan Kebudayaan Republik Indonesia Nomor: 431/Dikti/Kep/1995. Visi FSRD Universitas Trisakti adalah menjadi Fakultas Seni Rupa dan Desain yang andal di Indonesia, mempunyai standar Internasional dalam keilmuannya, dengan tetap memperhatikan tradisi dan kearifan lokal dalam mengembangkan seni, desain, ilmu pengetahuan dan teknologi, guna meningkatkan kualitas hidup dan peradaban. Saat ini Fakultas Seni Rupa dan Desain mempunyai 6 Program Studi yang terdiri dari: 4 Program Studi Sarjana yaitu Program Studi Desain Interior, Program Studi Desain Produk, Program Studi Desain Komunikasi Visual, Program Studi Fotografi; Program Studi Magister Desain Produk dan Program Diploma 3 Desain Komunikasi Visual (Usakti, 2020).

Pada tahun 2017, Fakultas Seni Rupa dan Desain Universitas Trisakti memiliki identitas baru. Logo di bawah merupakan identitas baru yang dibuat oleh Agus Adhityatama, S.Sn, M.Ds sebagai dosen Program Studi Desain Komunikasi Visual. Logo terdiri dari logogram dan logotype. Berdasarkan logo tersebut, Fakultas Seni Rupa dan Desain kini memiliki corporate color yaitu hijau tosca dengan color code \#29BAA5, R: 41 G: 186 B: 165, dan C: 72 M: 0 Y: 44 K: 0. Selain itu terdapat pula corporate typography yaitu Din font, yang memiliki typeface family di antaranya Din Light font, Din Medium font, Din Black font, Din Bold font, dan Din Bold Italic font.

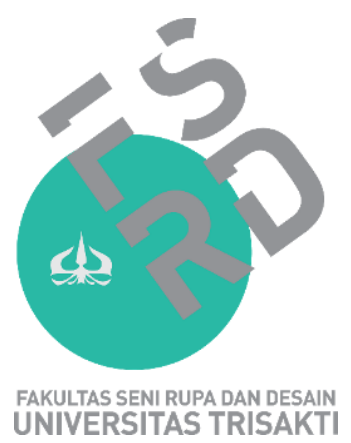

Gambar 1. Logo Fakultas Seni Rupa dan Desain Universitas Trisakti [Sumber: Agus Adhityatama, 2019] 


\subsection{Media Sosial Instagram @fsrdusakti}

Media sosial Instagram merupakan salah satu bentuk media massa berbasis visual dalam perkembangan dunia digital saat ini. Sebagai media baru, media sosial Instagram merupakan salah satu wujud budaya visual yang berbaur dalam dinamika kebudayaan manusia saat ini. Budaya visual (visual culture) menurut Sachari, 2007 adalah salah satu wujud kebudayaan manusia yang dapat ditangkap oleh indera visual dan dapat dipahami sebagai model pikiran manusia untuk meningkatkan kualitas hidupnya (Wardoyo, 2020).

Instagram post @fsrdusakti pertama diunggah pada 10 April 2016 tentang Desa Rupa Expo 2014 disukai oleh 8 orang. Berdasarkan observasi visual yang dilakukan oleh Fahira Nur Adita Putri pada 7 April 2019, akun @fsrdusakti memiliki 1.122 pengikut dan sudah mengikuti 128 akun Instagram lainnya.
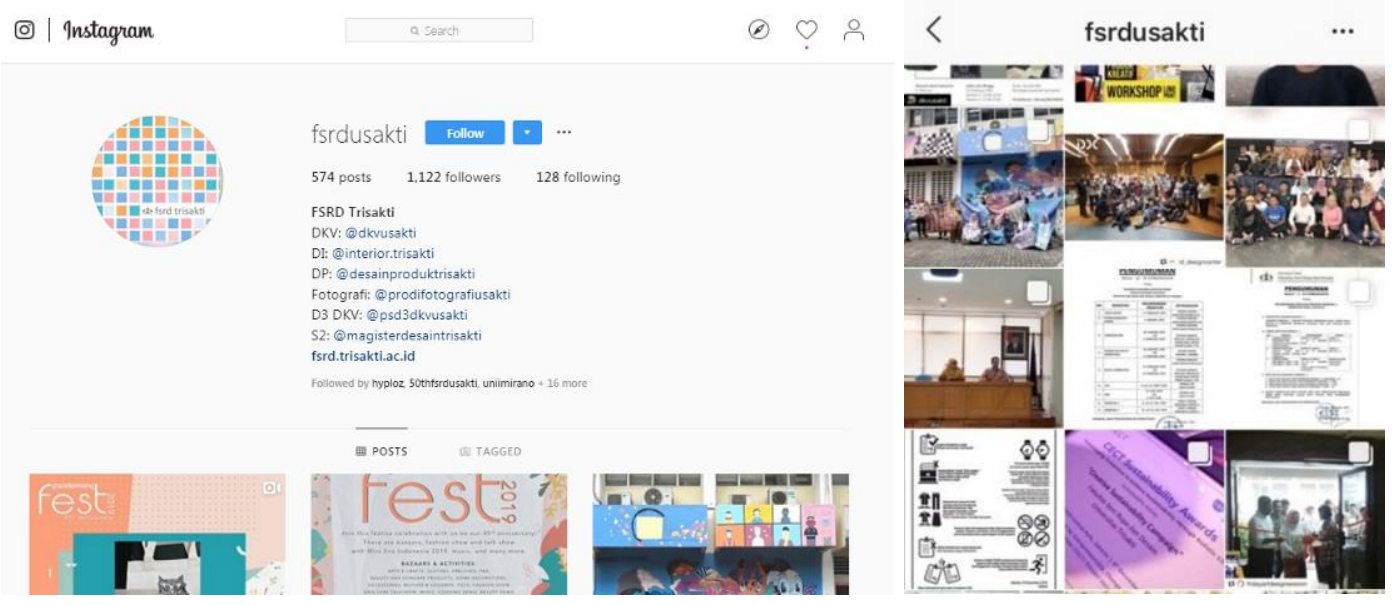

Gambar 2. Tampilan Desain Lama Instagram @fsrdusakti [Sumber: Fahira Nur Adita Putri, 2019]

Secara visual, konten akun media sosial Instagram @fsrdusakti hanya menampilkan foto biasa pada umumnya. Konten tidak memiliki identitas visual dari Fakultas Seni Rupa dan Desain Universitas Trisakti. Identitas visual yang dimaksud yaitu tidak adanya unsur logo, corporate color, corporate typography, bahkan corporate graphic elements. Pada bagian foto profilpun foto yang digunakan bukanlah logo FSRD Universitas Trisakti yang seharusnya. Konten yang diunggah juga tidak tertata atau diatur terlebih dahulu, sehingga Instagram feeds terlihat tidak rapi (Putri, 2019).

Tampilan baru akun media sosial Instagram @fsrdusakti merupakan karya Fahira Nur Adita Putri, mahasiswa Tugas Akhir Program Studi Desain Komunikasi Visual Semester Genap 2018/2019 dengan judul “Perancangan Media Promosi Fakultas Seni Rupa dan Desain Melalui Media Sosial Instagram: Studi Kasus Akun Instagram @fsrdusakti". Perancangan desain visual akun Instagram @fsrdusakti sebagai media promosi Fakultas Seni Rupa dan Desain Universitas Trisakti memiliki konsep yang dinamis, sehingga ke depannya desain dapat lebih dikembangkan agar tidak monoton. Desain konten menampilkan ragam warna dan karakter yang melekat pada Fakultas Seni Rupa dan Desain Universitas Trisakti. Perancangan ini dibuat lebih berbeda dari media sosial Instagram milik institusi lainnya, yaitu dengan penggunaan ilustrasi yang lebih dominan 
pada setiap konten akademiknya, elemen grafis, warna-warna dan layout yang variatif. Hal tersebut disesuaikan dengan perkembangan konten kreatif di media sosial Instagram saat ini. Isi konten tak hanya sekedar informasi berbentuk teks atau foto, tapi dikemas juga dengan ilustrasi dan layout yang menarik. Setiap konten tetap diterapkan logo, corporate typography, dan corporate color dari Fakultas Seni Rupa dan Desain Universitas Trisakti.

Media sosial merupakan salah satu media yang digunakan untuk menciptakan brand equity dan brand awareness, dalam persaingan antar institusi pendidikan tinggi desain khususnya di Indonesia. Brand equity atau ekuitas merek merupakan pembeda khas, unik dan positif yang ditimbulkan oleh pengetahuan nama merek terhadap interpretasi konsumen atas produk atau jasa. Ekuitas merek dapat dilihat dari respon konsumen terhadap komunikasi pemasaran yang dilakukan merek tersebut, sedangkan brand awareness merupakan kemampuan pelanggan potensial untuk mengenali dan mengingat merek dalam kategori tertentu (Rahmadianto \& Melany, 2018).

\subsection{Evaluasi Desain Media Sosial Instagram @fsrdusakti}

Survei dilakukan terhadap 116 responden melalui Google Form yang diedarkan melalui Whatsapp. Dari hasil kuesioner yang dikumpulkan, sebanyak 116 responden (100\%) merupakan pengguna Instagram. Berdasarkan kelompok usia adalah 15,5\% responden Usia 15-18 tahun; 53,4\% responden Usia 19-24 tahun; 17,2\% responden Usia 25-40 tahun; dan $13,8 \%$ responden Usia di atas 40 tahun. Sebanyak 8,6\% responden Pelajar SMA; 58,6\% responden Mahasiswa; 13,8\% responden Dosen; 14,7\% responden Karyawan; 4,4\% responden Wiraswasta/Freelancer.
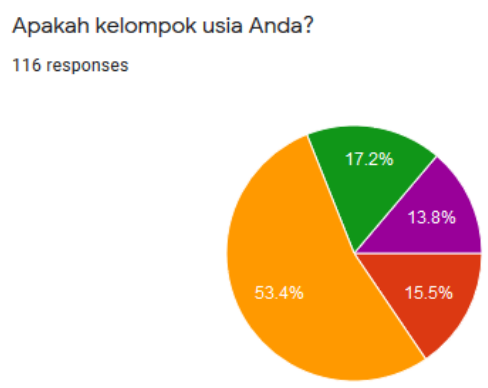

Di bawah 15 tahun

$15-18$ tahun

25 - 40 tahun

- Di atas 40 tahun

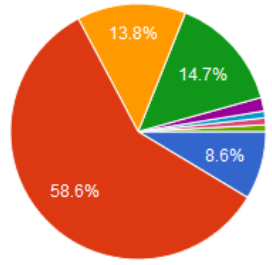

Gambar 3. Usia dan Pekerjaan Responden

[Sumber: Elda Franzia Jasjfi, 2020] 
Tidak semua responden mengikuti akun Instagram @fsrdusakti. Sebanyak 77,6\% responden merupakan Follower, dan sisanya 22,4\% responden bukan Follower. Pertanyaan kepada responden terkait elemen desain warna pada akun Instagram @fsrdusakti difokuskan pada tujuan mendapatkan informasi tentang keberhasilan penggunaan elemen warna untuk penyampaian branding FSRD Universitas Trisakti dan program studi-program studi di dalamnya.

Secara objektif atau fisik, warna merupakan sifat cahaya berupa panjang gelombang yang dipancarkan, sedangkan secara subjektif atau psikologis, warna merupakan pengalaman indera penglihatan dan berkaitan dengan persepsi. Interaksi layar dan mata manusia menghasilkan warna sebagai unsur estetis dan menjadi daya tarik visual (Swasty \& Utama, 2017).

Warna hijau tosca merupakan corporate color FSRD Universitas Trisakti yang juga terdapat pada akun Instagram @fsrdusakti. Warna hijau tosca memiliki makna energi dan ekspresi yang dinamis, untuk merepresentasikan FSRD Universitas Trisakti sebagai lembaga pendidikan tinggi seni rupa dan desain yang kaya akan gagasan dan inovasi, kreatif menjawab tantangan kemajuan zaman serta mudah menyesuaikan diri dalam kerja sama yang harmonis. Pada desain Instagram @fsrdusakti warna hijau tosca terdapat pada profil yaitu dalam bentuk logo FSRD Universitas Trisakti, icon Highlight Pengumuman, dan logo yang terdapat pada konten post pada akun ini (warna hijau tosca ditandai dengan garis kotak warna merah). Sebanyak $87,9 \%$ responden menyetujui bahwa warna hijau tosca sebagai corporate color sudah tercermin dalam desain Instagram @fsrdusakti. Hal ini disebabkan karena logo FSRD Universitas Trisakti secara konsisten ditampilkan pada konten, dan menjadi identifikasi identitas FSRD Universitas Trisakti. Selain itu warna hijau tosca juga terdapat pada twibbon yang digunakan untuk kegiatan Fakultas. Pada gambar di bawah twibbon berwarna hijau tosca ditunjukkan dengan garis kotak warna merah. Konten tersebut menampilkan kegiatan Rapat Kerja Dewan Riset Fakultas, Rapat Kerja Organisasi Kemahasiswaan FSRD, Seminar, dan Kegiatan Audit Internal FSRD Universitas Trisakti.
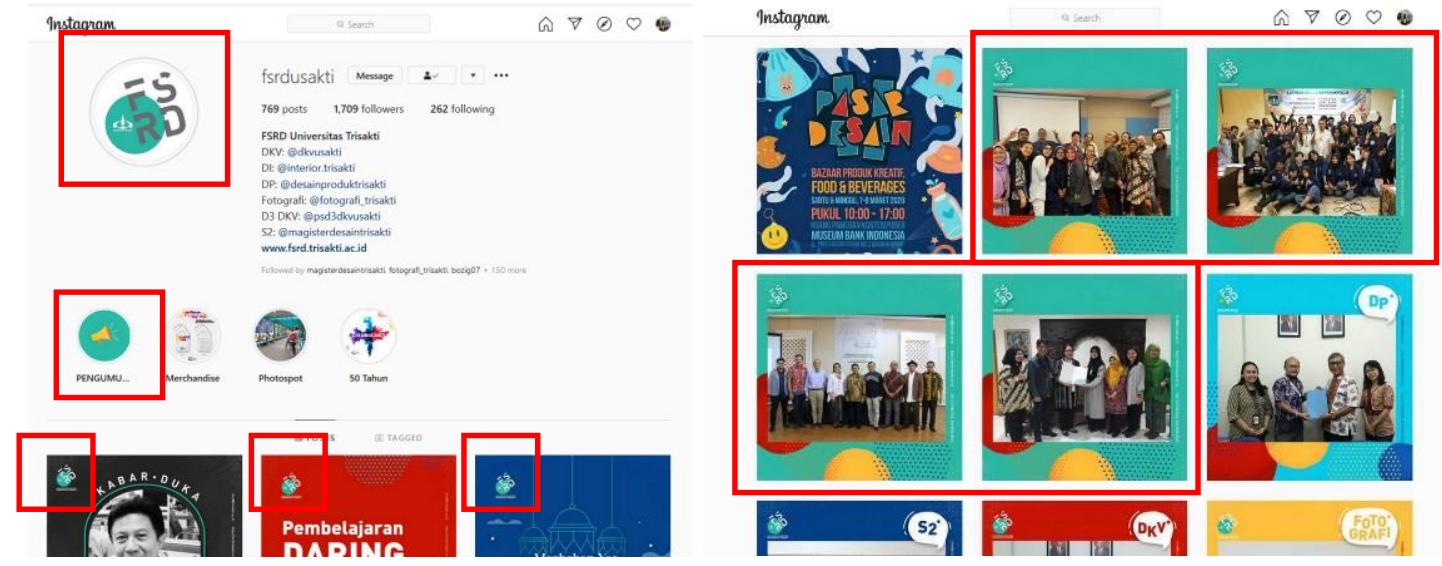

Gambar 4. Warna Hijau Tosca pada Instagram @fsrdusakti [Sumber: https://www.instagram.com/fsrdusakti/, 2020] 
Desain baru pada Instagram @fsrdusakti menggunakan twibbon yang berfungsi sebagai identifikasi konten-konten yang merupakan kegiatan program studi. Twibbon tersebut dibedakan berdasarkan warna-warna tertentu. Sebanyak $71,6 \%$ responden memahami adanya perbedaan klasifikasi warna berdasarkan Program Studi yang terdapat pada akun Instagram @fsrdusakti. Berdasarkan konsep desain baru Instagram @fsrdusakti, masing-masing warna merepresentasikan program studi dengan makna tertentu (Putri, 2019).
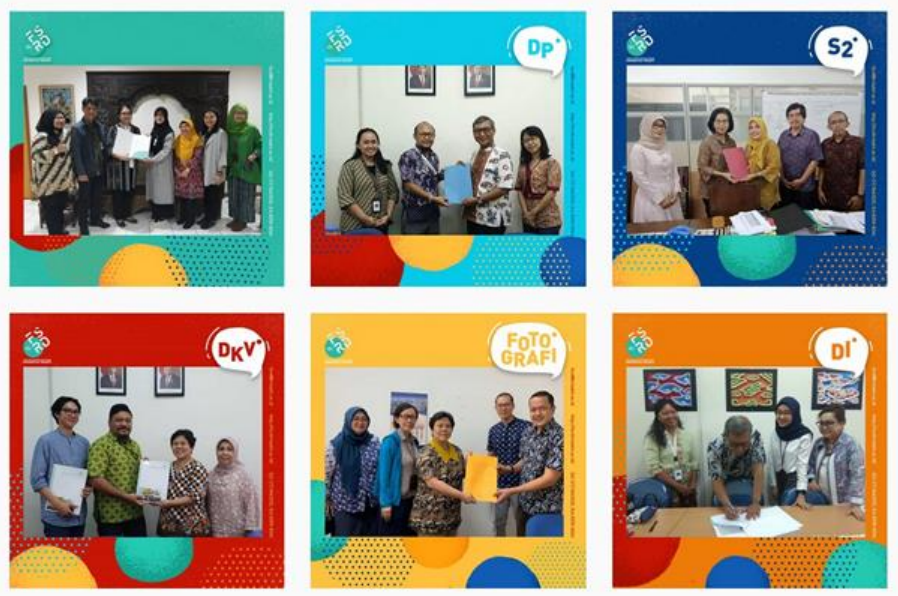

Gambar 5. Klasifikasi Warna Prodi pada Twibbon Instagram @fsrdusakti

[Sumber: https://www.instagram.com/fsrdusakti/, 2020]

Warna merah digunakan pada twibbon yang mewakili program studi Desain Komunikasi Visual. Warna merah dipilih karena mencerminkan lingkup kerja Desain Komunikasi Visual yang berani berkespresi dalam setiap karyanya, dan memberikan kesan semangat, kuat, dan berani. Sebanyak $83,6 \%$ responden setuju bahwa warna merah sesuai untuk program studi Desain Komunikasi Visual. Warna oranye digunakan sebagai warna yang mewakili program studi Desain Interior. Warna tersebut dipilih karena berkesan hangat dan berhubungan dengan warna bumi yang menjadi unsur warna dalam lingkup kerja Desain Interior. Sebanyak $77,6 \%$ responden setuju dengan penggunaan warna orange untuk Program Studi Desain Interior. Warna biru muda digunakan untuk merepresentasikan Program Studi Desain Produk. Warna ini dipilih karena berhubungan dengan lingkup kerja desain produk yang tidak hanya membutuhkan softskill namun juga hardskill dalam lingkup bengkel. Warna biru muda juga mencerminkan teknologi dan industri, serta memberikan kesan percaya diri. Sebanyak $86,2 \%$ responden setuju dengan penggunaan warna biru muda untuk Program Studi Desain Produk. Warna kuning merupakan warna yang mewakili Program Studi Fotografi. Warna kuning dipilih karena warna tersebut berhubungan dengan komponen terpenting yang dibutuhkan dalam lingkup kerja Fotografi di luar maupun di dalam ruangan, yaitu cahaya. Sebanyak $89,7 \%$ responden sesuai dengan penggunaan warna kuning untuk Program Studi Fotografi. Warna biru tua merupakan perwakilan warna dari Program Studi Magister Desain Produk. Warna tersebut dipilih karena memberikan kesan profesional dan terpercaya, sesuai dengan karakter mahasiswa/i Magister yang sudah lebih dewasa dan satu tingkat di atas program studi Sarjana. Sebanyak $94,8 \%$ responden setuju dengan penggunaan warna biru tua untuk Program Studi Magister 
Desain Produk. Warna hijau tosca muda menjadi warna identitas bagi Program Studi D3 Desain Komunikasi Visual, karena warna tersebut sesuai dengan lingkup belajarnya yang lebih dominan pada praktik. Sebanyak $86,2 \%$ responden setuju dengan penggunaan warna hijau tosca muda untuk Program Studi D3 Desain Komunikasi Visual.

Pertanyaan kepada responden terkait karakter ilustrasi pada akun Instagram @fsrdusakti difokuskan pada pemahaman penyampaian karakter ilustrasi untuk mencerminkan profil mahasiswa FSRD Universitas Trisakti. Sebanyak 94\% responden menganggap bahwa karakter ilustrasi pada akun Instagram @fsrdusakti menarik, dan $6 \%$ responden menganggap tidak menarik. Karakter-karakter tersebut diperkenalkan pada konten awal yang menandai perubahan desain lama ke desain baru Instagram @fsrdusakti. Pengenalan karakter ilustrasi berfokus pada pengenalan ragam karakter yang merepresentasikan civitas akademika FSRD Universitas Trisakti dan tidak menekankan pada apa dan siapa karakter tersebut. Oleh karena itu karakter-karakter tidak diasosiasikan pada penamaan dan latar belakang karakter, melainkan membuka peluang kepada pengguna untuk memahami secara visual perbedaan antar karakter tersebut.
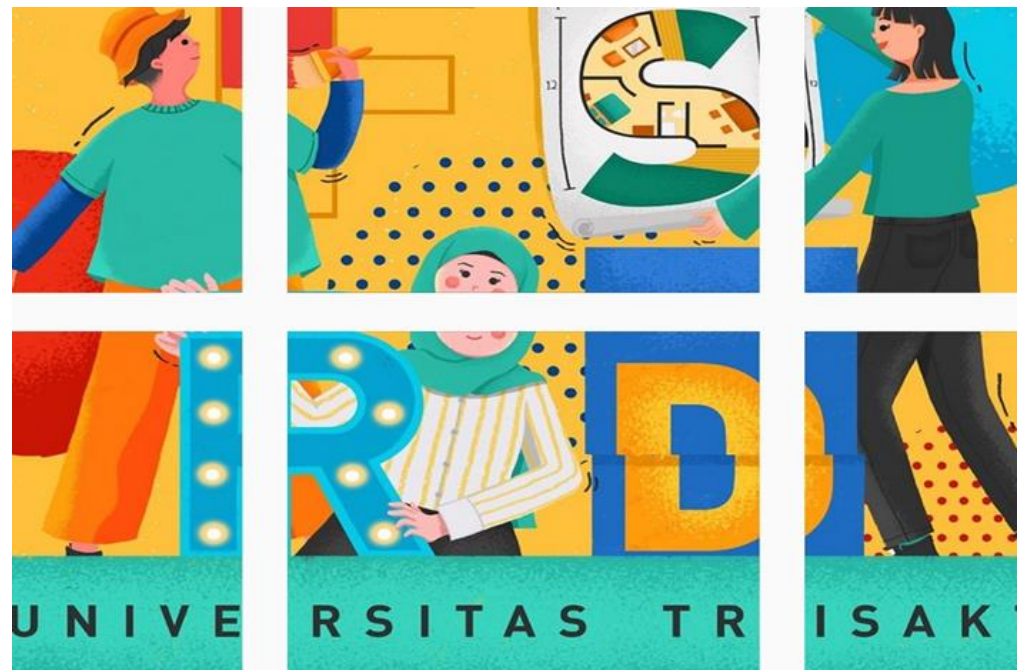

Gambar 6. Posting 6 Kotak Perkenalan Karakter Ilustrasi pada Instagram @fsrdusakti [Sumber: https://www.instagram.com/fsrdusakti/, 2020]

Ilustrasi berfungsi memperjelas sebuah informasi dan memberi representasi secara visual. Untuk itu diperlukan kemampuan pemikiran analitik dan praktis untuk membuat bentuk visual yang memiliki pesan. Ilustrasi memiliki peran komunikasi visual sebagai (1) alat informasi, (2) alat penyampaian opini, (3) alat untuk bercerita, (4) alat persuasi, (5) sebagai identitas, dan (6) sebagai desain (Witabora, 2012).

Karakter ilustrasi adalah entitas individu yang diambil dari karakteristik tertentu, dapat berdiri sendiri maupun saling mendukung antar karakter. Karakter memiliki personaliti tertentu, yang divisualisasikan melalui personal traits seperti gaya berpakaian, tampilan visual, tingkah laku, dan interaksi (Hedgpeth \& Missal, 2006). Sebanyak 89,7\% responden berpendapat bahwa karakter ilustrasi pada Instagram @fsrdusakti mencerminkan profil mahasiswa FSRD Universitas Trisakti, dan 10,3\% responden 
berpendapat tidak. Gaya visual karakter ilustrasi mendapat perhatian pengguna. Beberapa pengguna berpendapat bahwa karakter divisualisasikan kurang dewasa, dan lebih sesuai untuk usia SMP-SMA. Selain itu gaya karakter yang flat disarankan perlu mendapat penambahan shading dan lebih detail. Penggunaan karakter ilustrasi dapat dikembangkan dengan penggabungan teknik animasi dan gaya desain lain terkait dengan perkembangan era gaya visual desain.

Pertanyaan kepada responden terkait desain feed pada akun Instagram @fsrdusakti difokuskan pada bagaimana pesan komunikasi visual disampaikan melalui tata letak dan konten feed. Sebanyak 93,1\% responden menganggap desain baru Instagram @fsrdusakti telah mencerminkan karakter yang ingin ditampilkan, yaitu "Ekspresif", "Kreatif", dan "Fleksibel", sedangkan 6,9\% responden menjawab tidak. Tata letak feed pada Instagram @fsrdusakti disusun berdasarkan sistem ukuran square pada aplikasi Instagram dengan penggunaan terbanyak pada konten meliputi 1 square dan ada beberapa konten yang menggunakan 3 squares. Pengecualian pada konten pertama pengenalan desain Instagram @fsrdusakti yang baru, yang menggunakan sistem 6 squares. Desain feed terbentuk dari variasi konten yang meliputi konten informasi kegiatan fakultas dan program studi, konten peringatan hari besar, dan konten informasi lainnya. Variasi dan kombinasi konten tersebut menghasilkan kombinasi warna-warna yang menjadi desain feed pada Instagram @fsrdusakti.

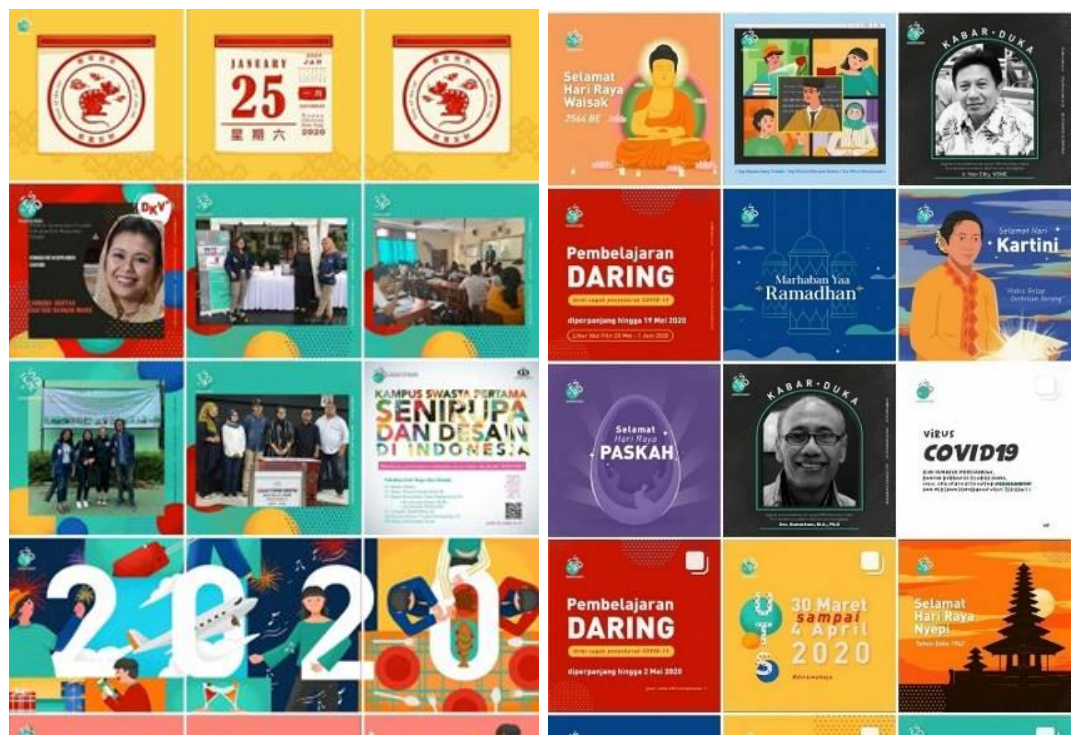

Gambar 7. Desain Feed pada Instagram @fsrdusakti

[Sumber: https://www.instagram.com/fsrdusakti/, 2020]

Desain feed merupakan pengaturan tata letak pada media sosial Instagram yang dilakukan berdasarkan grid. Grid adalah garis-garis maya yang membagi bidang layout. Desain feed Instagram terdiri dari panel-panel berukuran persegi. Setiap foto unggahan akan muncul pada posisi foto kiri atas dan kemudian akan bergeser ke kanan setiap ada unggahan baru yang muncul. Sebanyak $92,2 \%$ responden menganggap bahwa desain baru Instagram @fsrdusakti telah berhasil membentuk branding baru untuk Fakultas Seni Rupa dan Desain Universitas Trisakti, dan sebanyak 7,8\% responden menganggap 
tidak terbentuk branding baru meskipun telah ada desain baru Instagram @fsrdusakti tersebut.

Apakah desain baru Instagram @fsrdusakti berhasil membentuk branding baru FSRD Universitas Trisakti?

116 responses

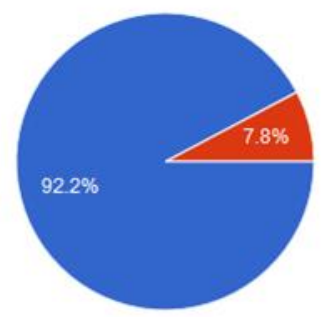

$$
\text { Ya }
$$

- Tidak

Gambar 8. Desain Baru Instagram @fsrdusakti Berhasil Membentuk Branding Baru

[Sumber: Elda Franzia Jasjfi, 2020]

Sebanyak $94 \%$ responden memandang perlunya pengembangan lebih lanjut pada desain feed Instagram @fsrdusakti, dan hanya 6\% responden yang menganggap desain feed tidak perlu dikembangkan lagi. Untuk kebutuhan pengembangan desain feed, sebanyak $56,9 \%$ responden menyarankan desain Semiformal sesuai dengan karakteristik Fakultas Seni Rupa dan Desain Universitas Trisakti, sedangkan sebanyak $31,9 \%$ responden lebih menyarankan desain yang Informal, dan $11,2 \%$ responden menyarankan desain yang Formal untuk Instagram @fsrdusakti.

Tema feed Instagram diperlukan untuk membentuk identitas brand Fakultas Seni Rupa dan Desain Universitas Trisakti. Pada media sosial Instagram, pengguna terkoneksi dengan visual untuk menangkap pesan komunikasi visual tentang branding yang ingin disampaikan. Desain feed Instagram secara keseluruhan menghimpun elemen-elemen visual warna, karakter ilustrasi, dan konten yang ditampilkan dalam feed, sehingga Instagram menjadi bagian dari komunikasi visual institusi untuk membangun branding.

Penanaman brand di benak pengguna dijalankan melalui internalisasi kesan-kesan, posisi dan persepsi secara visual pada media sosial Instagram. Desain yang spesifik dan konsisten memiliki daya pembeda dalam benak konsumen. Branding terbentuk melalui karakteristik desain akun media sosial Instagram sebagai identitas visual, yang menjadi lebih kaya dan menarik ketimbang atribut produk. Komunikasi visual yang dilakukan untuk penyampaian branding Fakultas Seni Rupa dan Desain Universitas Trisakti melalui Instagram @fsrdusakti dan hasil evaluasi desain untuk branding Fakultas Seni Rupa dan Desain Universitas Trisakti dapat dilihat pada Tabel 1 di bawah ini. 
Tabel 1. Branding pada Instagram @fsrdusakti

[Sumber: Elda Franzia Jasjfi, 2020]

\begin{tabular}{|c|c|c|c|}
\hline No. & Visual & Elemen Visual & Evaluasi Branding \\
\hline 1 & & $\begin{array}{l}\text { Logo pada } \\
\text { profil } \\
\text { Instagram } \\
\text { @fsrdusakti }\end{array}$ & $\begin{array}{l}\text { - Foto profil menampilkan logo FSRD } \\
\text { Universitas Trisakti. } \\
\text { - Branding telah ditampilkan dalam } \\
\text { bentuk simbol yang diasosiasikan } \\
\text { dengan institusi. }\end{array}$ \\
\hline 2 & $\begin{array}{l}\text { FSRD Universitas Trisakti } \\
\text { College \& University }\end{array}$ & Nama & $\begin{array}{l}\text { - Nama institusi ditampilkan sebagai } \\
\text { identitas akun Instagram } \\
\text { @fsrdusakti. } \\
\text { - Tampilan nama merupakan brand } \\
\text { name yang bersifat sebagai } \\
\text { identifikasi merek. }\end{array}$ \\
\hline 3 & & $\begin{array}{l}\text { Warna } \\
\text { hijau tosca }\end{array}$ & $\begin{array}{l}\text { - Warna hijau tosca digunakan } \\
\text { dalam twibbon yang } \\
\text { merepresentasikan kegiatan } \\
\text { Fakultas. } \\
\text { - Warna hijau tosca yang digunakan } \\
\text { sama dengan warna pada logo } \\
\text { FSRD Universitas Trisakti. } \\
\text { - Branding ditampilkan melalui } \\
\text { warna hijau tosca sebagai } \\
\text { corporate color FSRD Universitas } \\
\text { Trisakti. }\end{array}$ \\
\hline 4 & 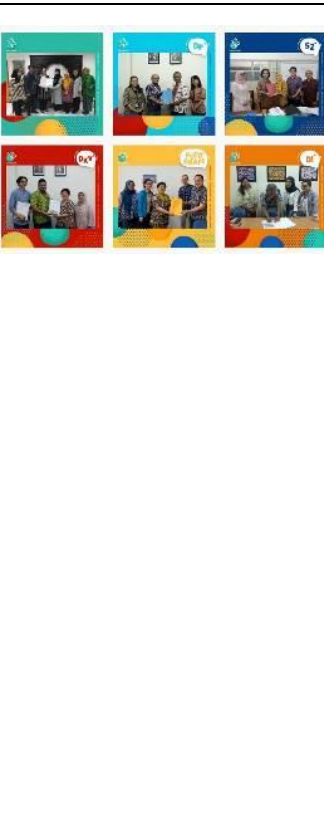 & $\begin{array}{l}\text { Warna-warna } \\
\text { program studi }\end{array}$ & $\begin{array}{l}\text { - Masing-masing warna } \\
\text { merepresentasikan program studi } \\
\text { berdasarkan pemaknaan pada } \\
\text { konsep desain. } \\
\text { - Makna masing-masing warna tidak } \\
\text { dipahami oleh responden. } \\
\text { - Penggunaan warna-warna } \\
\text { menimbulkan kesan cerah dan } \\
\text { menarik. } \\
\text { - Penggunaan warna pada } \\
\text { keseluruhan feed perlu } \\
\text { perencanaan. } \\
\text { - Penggunaan warna-warna yang } \\
\text { terlalu kuat mengurangi warna } \\
\text { hijau tosca sebagai corporate color } \\
\text { FSRD Universitas Trisakti. }\end{array}$ \\
\hline
\end{tabular}




\begin{tabular}{|c|c|c|c|}
\hline No. & Visual & Elemen Visual & Evaluasi Branding \\
\hline 5 & $n y$ & $\begin{array}{l}\text { Karakter } \\
\text { ilustrasi }\end{array}$ & $\begin{array}{l}\text { - Karakter ilustrasi digunakan } \\
\text { sebagai representasi karakteristik } \\
\text { mahasiswa FSRD Universitas } \\
\text { Trisakti. } \\
\text { - Konsep karakter ilustrasi mewakili } \\
\text { sifat ekspresif, kreatif, fleksibel. } \\
\text { - Karakter ilustrasi dinilai cukup } \\
\text { menarik, namun perlu } \\
\text { dikembangkan. } \\
\text { - Penggunaan karakter ilustrasi } \\
\text { diharapkan lebih beragam, variatif, } \\
\text { ceria, untuk menunjukkan } \\
\text { keberagaman dan kekinian FSRD } \\
\text { Universitas Trisakti. Kesan yang } \\
\text { diinginkan adalah kreatif, fun, dan } \\
\text { profesional. }\end{array}$ \\
\hline 6 & 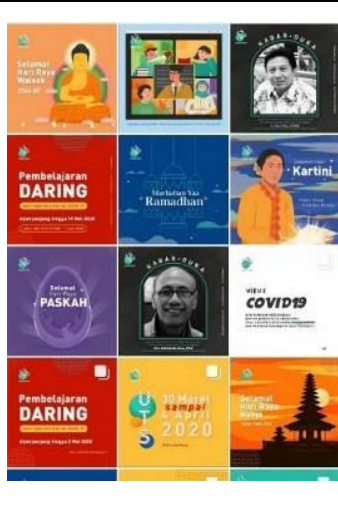 & Desain feed & $\begin{array}{l}\text { - Desain feed terbentuk dari } \\
\text { kombinasi konten post pada } \\
\text { Instagram @fsrdusakti. } \\
\text { - Desain feed berkesan Semiformal. } \\
\text { - Desain feed kurang terencana } \\
\text { dalam hal kombinasi warna dan } \\
\text { konten post. } \\
\text { - Branding melalui Instagram } \\
\text { @fsrdusakti terutama terbentuk } \\
\text { melalui desain feed. }\end{array}$ \\
\hline
\end{tabular}

\section{KESIMPULAN}

Pada akun Instagram @fsrdusakti kekuatan warna dan nuansa warna yang kuat langsung ditangkap oleh pengguna. Namun warna-warna yang didesain sebagai representasi karakteristik masing-masing program studi tidak langsung ditangkap dan tidak dipahami oleh pengguna, karena belum ada konten yang menjelaskan tentang makna warna-warna tersebut. Corporate color Fakultas Seni Rupa dan Desain yaitu hijau tosca dapat terlihat melalui logo namun tidak ditampilkan terlalu kuat sebagai corporate color untuk kebutuhan branding Fakultas Seni Rupa dan Desain Universitas Trisakti. Meskipun warna-warna kuat dinilai menarik, namun disarankan untuk menggunakan warna pada konten secara lebih terencana dan lebih menguatkan warna hijau tosca sebagai corporate color dan bukan terlihat warna-warni.

Selain elemen warna, elemen ilustrasi juga merupakan elemen yang menarik perhatian pengguna pada Instagram @fsrdusakti. Karakter ilustrasi didesain untuk menimbulkan kesan informal pada akun media sosial Fakultas Seni Rupa dan Desain, sehingga diharapkan dapat lebih menarik bagi usia muda dan merepresentasikan branding yang 
"Ekspresif", "Kreatif", dan "Fleksibel". Namun gaya visual pada karakter ilustrasi yang ditampilkan menimbulkan berbagai pendapat dari responden, karena gaya visual sering kali berkaitan erat dengan subjektivitas pengguna. Pendapat dan masukan untuk menampilkan karakter ilustrasi yang lebih detail, lebih ekspresif, atau lebih dewasa, menjadi masukan dari responden.

Penyampaian pesan komunikasi visual melalui desain feed Instagram @fsrdusakti dipengaruhi oleh tata letak dan konten feed yang tampil melalui elemen warna dan karakter ilustrasi. Desain feed pada media sosial Instagram dapat menimbulkan kesan dan pengalaman visual dari pengguna. Kualitas gambar baik foto, video, dan ilustrasi merupakan aspek penting yang perlu diperhatikan untuk kepuasan pengguna. Responden menangkap desain feed secara keseluruhan berkesan Semiformal, meskipun sebagian responden juga menangkap kesan Informal dan Formal. Hal tersebut dipengaruhi subjektivitas responden, yaitu usia dan pengalaman visual responden yang tidak diteliti lebih lanjut pada penelitian ini. Terkait dengan itu adalah harapan responden pada desain feed Instagram @fsrdusakti yang dominan mengharapkan kesan Semiformal, meskipun harapan terhadap kesan Informal meningkat dibanding kesan Formal.

Dengan demikian berdasarkan hasil penelitian dapat disimpulkan bahwa, secara umum desain baru Instagram @fsrdusakti telah mencapai tujuan utamanya yaitu menyampaikan branding Fakultas Seni Rupa dan Desain Universitas Trisakti melalui desain baru yang dimulai pada perayaan 50 tahun FSRD Universitas Trisakti yang lalu, namun secara evaluatif desain masih harus dikembangkan untuk kebutuhan ketepatan komunikasi visual yang lebih efektif kepada khalayak sasaran.

\section{DAFTAR PUSTAKA}

Atiko, G., Sudrajat, R. H., \& Nasionalita, K. (2016). Analisis Strategi Promosi Pariwisata Melalui Media Sosial Oleh Kementrian Pariwisata RI (Studi Deskriptif pada Akun Instagram @indtravel). Jurnal Sosioteknologi, 15(3), 378-389.

FSRD Universitas Trisakti. (2020). Retrieved March 20, 2020, from https://www.instagram.com/fsrdusakti/

Hedgpeth, K., \& Missal, S. (2006). Exploring Character Design. New York: Thomson Delmar Learning.

Indika, D. R., \& Jovita, C. (2017). Media Sosial Instagram Sebagai Sarana Promosi Untuk Meningkatkan Daya Beli Konsumen. Jurnal Bisnis Terapan, 1(01), 25-32.

Kemp, S. (2019). Global Digital Report 2019. Retrieved from https://wearesocial.com/global-digital-report-2019

Putri, F. N. A. (2019). Perancangan Media Promosi Fakultas Seni Rupa dan Desain Melalui Media Sosial Instagram: Studi Kasus Akun Instagram @fsrdusakti. Universitas Trisakti.

Rahmadianto, S. A., \& Melany. (2018). Perancangan Multimedia Interaktif Pengenalan DKV Ma Chung Sebagai Upaya Meningkatkan Brand Equity. Jurnal Andharupa, 04(02), 130-142.

Swasty, W., \& Utama, J. (2017). Warna Sebagai Identitas Merek pada Website. Jurnal 
Andharupa, 03(01), 1-16.

Usakti, F. (2020). Tentang FSRD. Retrieved March 20, 2020, from http://fsrd.trisakti.ac.id/

Wardoyo, B. T. (2020). Budaya Visual pada Website Fakultas Seni Rupa dan Desain Universitas Trisakti. Jurnal Andharupa, 06(01), 125-134.

Witabora, J. (2012). Peran dan Perkembangan Ilustrasi. Jurnal Humaniora, 3(2), 659667. Retrieved from https://media.neliti.com/media/publications/167371ID-peran-dan-perkembangan-ilustrasi.pdf 